\title{
Comment on "Ab Initio Study of the Structural, Elastic, Electronic and Optical Properties of $\mathrm{Cu}_{3} \mathrm{~N}$ " [Materials Research. 2014;17(2):303-310]
}

\author{
Salah Daoud ${ }^{a}$ * \\ ${ }^{a}$ Laboratoire Matériaux et Systèmes Electroniques - LMSE, Université Mohamed Elbachir El Ibrahimi \\ de Bordj Bou Arreridj, Bordj Bou Arreridj, 34000, Algérie
}

Received: October 6, 2015; Accepted: December 16, 2015

\begin{abstract}
Recently, Rahmati et al., ${ }^{1}$ have published a paper in Materials Research 2014; 17(2): 303-310. They have investigated the structural, elastic, electronic and optical properties of $\mathrm{Cu}_{3} \mathrm{~N}$ in its phase cubic anti- $\mathrm{ReO}_{3}$ structure. But it is to be noted, that the numerical values of the density, the longitudinal $\left(\mathrm{v}_{\mathrm{f}}\right)$, transverse $\left(\mathrm{v}_{\mathrm{t}}\right)$ and average $\left(\mathrm{v}_{\mathrm{m}}\right)$ elastic wave velocities, and the Debye temperature obtained by Rahmati et al., ${ }^{1}$ seem to be inaccurate. These errors are certainly due to the inaccuracy application of the formula used to calculate the density. In the present comment, we recalculated, and we gave the right numerical values of the density, the longitudinal $\left(\mathrm{v}_{1}\right)$, transverse $\left(\mathrm{v}_{\mathrm{t}}\right)$ and average sound velocity $\left(\mathrm{v}_{\mathrm{m}}\right)$ and of the Debye temperature of $\mathrm{Cu}_{3} \mathrm{~N}$ material, based on the lattice parameter and the elastic constants obtained in their work.
\end{abstract}

Keywords: Copper nitride $\left(\mathrm{Cu}_{3} \mathrm{~N}\right)$ material, Sound velocity, Debye temperature

The numerical values of the density, the longitudinal $\left(v_{l}\right)$, transverse $\left(v_{t}\right)$, and average $\left(v_{m}\right)$ elastic wave velocities, and the Debye temperature of $\mathrm{Cu}_{3} \mathrm{~N}$ material in its phase cubic anti- $\mathrm{ReO}_{3}$ structure obtained by Rahmati et al., ${ }^{1}$ are illustrated in Table 1.

Firstly, it is to be noted that the numerical value of the density of $\mathrm{Cu}_{3} \mathrm{~N}$ material in its phase cubic anti- $\mathrm{ReO}_{3}$ structure obtained by Rahmati et al., ${ }^{1}$ illustrated in Table 1 is wrong.

Secondly, because the longitudinal $\left(v_{l}\right)$, transverse $\left(v_{t}\right)$ and average $\left(v_{m}\right)$ elastic wave velocities, and the Debye temperature $\theta_{D}$ are directly related to the density (please, see the formulas of equations. (6), (7) and (8) in the Ref. ${ }^{1}$ ), so also, the numerical values of $\left(v_{l}\right),\left(v_{t}\right),\left(v_{m}\right)$ and $\theta_{D}$ are also wrong.

The density of a crystal is intimately related to chemical composition (expressed in equation (1) by the molecular weight), and crystal structure (expressed in equation (1) by the number of molecules per unit cell and the unit cell volume) through the following relation ${ }^{2}$ :

$\rho=M Z / N_{A} V$

The density $\rho\left(\mathrm{kg} / \mathrm{m}^{3}\right)$ is determined by the molecular weight $M$ (in $10^{-3} \mathrm{~kg}$ ), the number of molecules per unit cell $Z$, Avogadro's number $N_{\mathrm{A}}$, and the unit cell volume $V\left(\right.$ in $\left.\mathrm{m}^{3}\right)$.

For cubic anti- $\mathrm{ReO}_{3}$-type crystal structure (Figure 1), there is only one molecule (formed form 4 atoms) per unit cell, so $Z=1$, and the unit cell volume $V=a^{3}$, where: $a$ is lattice parameter.

For the $\mathrm{Cu}_{3} \mathrm{~N}$ material: $\mathrm{M}=204.645 \times 10^{-3} \mathrm{~kg}$.

*e-mail: salah_daoud07@yahoo.fr
$\Rightarrow \rho=\left[\left(204.645 \times 10^{-3} \mathrm{~kg} \mathrm{x} 1\right)\right] /\left[\left(6.0221367 \times 10^{23}\right) \times\right.$ $\left.\left(\left(3.829 \times 10^{-10} \mathrm{~m}\right)^{3}\right)\right]=6053 \mathrm{~kg} \cdot \mathrm{m}^{-3}=6.053 \mathrm{~g} \cdot \mathrm{cm}^{-3}$

So, as we see, there is difference between this result and that illustrated in Table 1. This error is certainly due to the inaccuracy application of the formula used by Rahmati et al., ${ }^{1}$ to calculate the density.

So using the lattice parameter and the elastic constants obtained by Rahmati et al., ${ }^{1}$ of $\mathrm{Cu}_{3} \mathrm{~N}$ material in its phase cubic anti- $\mathrm{ReO}_{3}$ structure, the right numerical values of the density, the longitudinal $\left(v_{l}\right)$, transverse $\left(v_{t}\right)$ and average $\left(v_{m}\right)$ elastic wave velocities, and the Debye temperature are presented in Table 2.

So, as we see, also there are big differences between our results and those illustrated in Table 1. Taken for example the average elastic wave velocity $\left(v_{m}\right)$, the deviation between the value $(4563.9 \mathrm{~m} / \mathrm{s})$ obtained by Rahmati et al., ${ }^{1}$ and the value $(3539.1 \mathrm{~m} / \mathrm{s})$ obtained in this comment is about $29 \%$.

The deviation between the value $(353 \mathrm{~K})$ of the Debye temperature obtained by Rahmati et al., ${ }^{1}$ and the value ( $437 \mathrm{~K}$ ) obtained in this comment is about $19.2 \%$.

In conclusion, after reading the paper of Rahmati et al., ${ }^{1}$ it is observed that their numerical values of the density $\rho$, the longitudinal $\left(v_{l}\right)$, transverse $\left(v_{t}\right)$, and average $\left(v_{m}\right)$ sound velocities, and the Debye temperature of the Copper nitride $\left(\mathrm{Cu}_{3} \mathrm{~N}\right)$ material in its phase cubic anti- $\mathrm{ReO}_{3}$ structure are inaccurate. So, we recomputed, and we gave the right numerical values of the density, the longitudinal $\left(v_{l}\right)$, transverse $\left(v_{t}\right)$, and average $\left(v_{m}\right)$ sound velocities and the Debye temperature of $\mathrm{Cu}_{3} \mathrm{~N}$ material in its phase cubic anti- $\mathrm{ReO}_{3}$ structure, based on the lattice parameter and the elastic constants obtained in their work. 
Table 1. Numerical values of the density, the longitudinal (vl), transverse $\left(v_{t}\right)$ and average $\left(v_{m}\right)$ elastic wave velocities, and the Debye temperature of Cu3N material obtained by Rahmati et al. [1].

\begin{tabular}{cc}
\hline $\boldsymbol{\rho}\left(\mathbf{g} / \mathbf{c m}^{3}\right)$ & $\mathbf{3 . 6 4}$ \\
\hline$v_{l}(\mathrm{~m} / \mathrm{s})$ & 7372.4 \\
$v_{s}(\mathrm{~m} / \mathrm{s})$ & 4097.9 \\
$v_{m}(\mathrm{~m} / \mathrm{s})$ & 4563.9 \\
$\theta_{D}(\mathrm{~K})$ & 353 \\
\hline
\end{tabular}

Table 2. Right numerical values of the density, the longitudinal $\left(v_{l}\right)$, transverse $\left(v_{t}\right)$ and average $\left(v_{m}\right)$ sound velocities and Debye temperature of $\mathrm{Cu}_{3} \mathrm{~N}$ material.

\begin{tabular}{cc}
\hline$M\left(\mathbf{1 0} \mathbf{1}^{-3} \mathbf{~ k g}\right)$ & $\mathbf{2 0 4 . 6 4 5}$ \\
\hline$\rho\left(\mathrm{g} / \mathrm{cm}^{3}\right)$ & 6.053 \\
$v_{l}(\mathrm{~m} / \mathrm{s})$ & 5717.1 \\
$v_{t}(\mathrm{~m} / \mathrm{s})$ & 3177.8 \\
$v_{m}(\mathrm{~m} / \mathrm{s})$ & 3539.1 \\
$\theta_{D}(\mathrm{~K})$ & $\mathbf{4 3 7}$ \\
\hline
\end{tabular}

\section{References}

1. Rahmati A, Ghoohestani M, Badehian H, Baizaee M. Ab Initio Study of the Structural, Elastic, Electronic and Optical

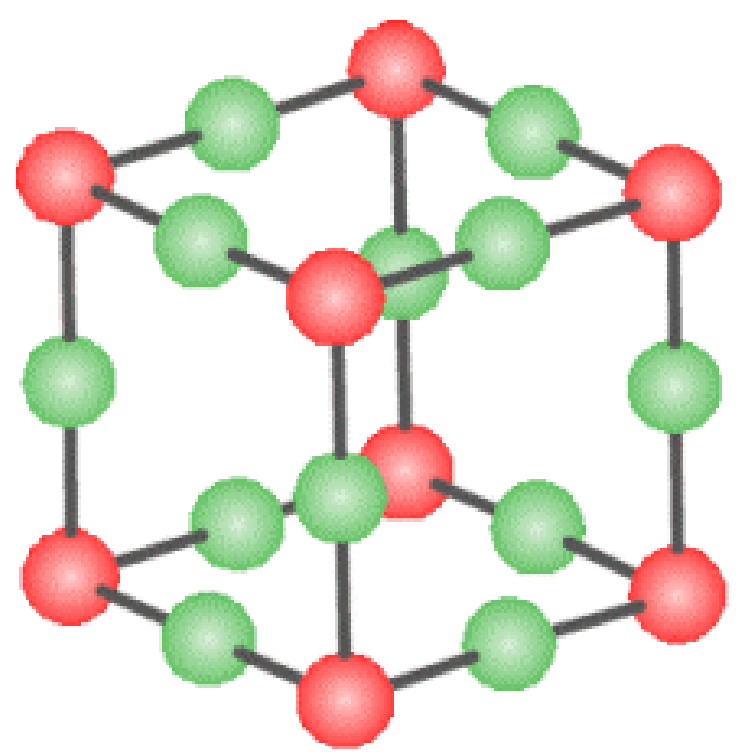

Figure 1. Cubic anti- $\mathrm{ReO}_{3}$-type crystal structure [1].

Properties of $\mathrm{Cu}_{3}$ N. Materials Research. 2014;17(2): 303-310. http://dx.doi.org/10.1590/S1516-14392014005000039.

2. Newnham RE. Properties of materials: anisotropy, symmetry, structure. Oxford University Press; 2005. 